\title{
Article \\ The Effects of Combined Pre and Postharvest Deficit Irrigation on Loquat Yield, Fruit Quality and Handling Aptitude
}

\author{
Juan J. Hueso $\left.{ }^{1}{ }^{(}\right)$, Francisca Alonso ${ }^{2}$, María L. Cañete ${ }^{3}{ }^{\circledR}$, Mónica González ${ }^{1}$, Virginia Pinillos ${ }^{3}{ }^{\circledR}$, Fernando \\ M. Chiamolera ${ }^{3}$ (D) and Julián Cuevas ${ }^{3, *(D)}$ \\ 1 Experimental Station of Foundation Cajamar, 04710 El Ejido, Almería, Spain; \\ juanjosehueso@fundacioncajamar.com (J.J.H.); monicagonzalez@fundacioncajamar.com (M.G.) \\ 2 Institute of Agricultural Research and Training (IFAPA), 04745 La Mojonera, Almería, Spain; \\ paquialonso10@gmail.com \\ 3 Department of Agronomy, University of Almería, ceiA3, 04120 Almería, Almería, Spain; \\ mluisa@ual.es (M.L.C.); vpinillo@ual.es (V.P.); chiamolera@hotmail.com (F.M.C.) \\ * Correspondence: jcuevas@ual.es; Tel.: +34-950-015559
}

check for updates

Citation: Hueso, J.J.; Alonso, F.; Cañete, M.L.; González, M.; Pinillos, V.; Chiamolera, F.M.; Cuevas, J. The Effects of Combined Pre and Postharvest Deficit Irrigation on Loquat Yield, Fruit Quality and Handling Aptitude. Agronomy 2021 11, 201. https://doi.org/10.3390/ agronomy11020201

Academic Editor: Daniela Romano, Juan A. Fernández and Gabriele Cola Received: 11 December 2020

Accepted: 18 January 2021

Published: 21 January 2021

Publisher's Note: MDPI stays neutral with regard to jurisdictional claims in published maps and institutional affiliations.

Copyright: (c) 2021 by the authors. Licensee MDPI, Basel, Switzerland. This article is an open access article distributed under the terms and conditions of the Creative Commons Attribution (CC BY) license (https:// creativecommons.org/licenses/by/ $4.0 /)$.

\begin{abstract}
Loquat prices depend on fruit size and earliness. Earliness is improved by postharvest deficit irrigation (DI), without negative effects on fruit size. An optimization of postharvest DI strategies carried out by limiting the dry period led to greater harvest date advancement, but water savings were reduced. To further improve fruit earliness and quality and increase water savings, we combined pre and postharvest DI strategies. Treatments were T1: trees not irrigated during six weeks after harvest (no preharvest DI applied); T2: trees that, in addition to postharvest DI, were not watered from the rapid fruit growth phase to harvest (nine extra weeks of DI); T3: trees that, in addition to postharvest DI, were not watered from color break to harvest (six weeks of DI plus postharvest DI); and T4: trees that in addition to postharvest DI were not watered during rapid fruit growth, but were re-irrigated at color break (2-3 weeks of DI, depending on the season). Full-irrigated trees were grown for comparison. T1 saved $18 \%$ water with respect to full-irrigation, and advanced harvesting by 16 days. T2 saved more water, had an earlier harvest and produced a higher early yield. Shorter dry periods were beneficial to a lower extent. Fruit size was significantly diminished by $\mathrm{T} 2$, but not by $\mathrm{T} 4$. A major advantage of $\mathrm{T} 3$ and $\mathrm{T} 4$ was the better performance of fruit during handling and shelf life. T2 fruits were favored by panelists for their sweetness but criticized for their smaller size.
\end{abstract}

Keywords: Eriobotrya japonica; water deficit; fruit aptitude; Algerie loquat; earliness

\section{Introduction}

Loquat (Eriobotrya japonica Lindl.; Rosaceae) is a subtropical evergreen fruit tree native of southeast China [1]. China is the leading country in acreage (133,000 ha) and production $(512,000 \mathrm{t})$, while Spain is the second producer reaching $28,836 \mathrm{t}$ from about $2250 \mathrm{ha}$, but the leading world exporter [2,3]. As apple and pear, loquat is a pome fruit, but contrary to them loquat fruit is non-climacteric and acidulous. Therefore, the harvest has to be carefully programmed in order to satisfy consumer expectations.

The price of loquat strongly depends on fruit quality and earliness. Loquat fruit quality is determined by their external appearance, including large fruit size, nice skin color and disorder absence, and by its organoleptic characteristics. In Spain, loquat ripens its fruits in early April, reaching the market before any other spring fruit. For this reason, the prices are high at the beginning of the season, when there is no competition with other fruit crops, dropping acutely when May arrives. This makes fruit earliness a major driver in loquat commercialization and profitability.

For the above reasons, any technique able to improve loquat earliness and fruit quality may have a significant impact on farmers' profits. Of great interest in semi-arid climates 
is to enhance loquat earliness by the modification of the reproductive phenology using postharvest deficit irrigation (DI) as a tool [4]. The optimization of DI strategies in loquat by determining the best dates [5], levels [6] and duration [7] allows an improvement in selling price (up to $€ 0.77 \mathrm{~kg}^{-1}$ ) without negative effects on fruit size or yield.

In addition to postharvest DI, a period of water withholding during fruit development (preharvest DI) can enhance some attributes of loquat fruits. On one hand, an additional period of irrigation withholding increases water savings. On the other hand, a wisely managed situation of water stress during fruit development and maturation can advance even more fruit ripening and improve the quality of the fruit by increasing sugar content, firmness and skin color as reported in apples [8], apricots [9] and cherries [10]. An important question that can be modified by preharvest DI is the diminution of loquat disorders, some already present at harvest time, but developed during fruit storage $[8,11]$. In this regard, loquat fruit is extremely susceptible to careless handling, easily showing damages such as browning, bruises and punctures, sometimes immediately after harvest, but more often after a few days of storage.

Having all this in mind, we designed an experiment aiming to increase water savings, enhance loquat earliness and improve fruit quality and performance during handling and at shelf life. Preliminary results have been published by Hueso et al. [12].

\section{Materials and Methods}

\subsection{Experimental Site and Management}

The trial was carried out during two consecutive seasons (2006/07 and 2007/08) in a plot of 'Algerie' loquat sited in the Experimental Station of the Cajamar Foundation in El Ejido (Almería, SE Spain; $36^{\circ} 48^{\prime} \mathrm{N}, 2^{\circ} 43^{\prime} \mathrm{W}$ and $151 \mathrm{~m}$ elevation). According to the agroclimatic classification of Papadakis, the annual climate of this area is semi-arid subtropical Mediterranean. Average annual temperatures and rainfall are $18.4^{\circ} \mathrm{C}$ and $241 \mathrm{~mm}$. The evaporation from a Class-A pan (Epan) measured at the experimental site reaches average values of $1992 \mathrm{~mm}$ per year. The rainfall in the area is scarce and erratic, taking place mostly in autumn and winter, and was not taken into account for the irrigation applications. In this regard, total rainfall in season 2006/07 was $362 \mathrm{~mm}$ and $202 \mathrm{~mm}$ in the following season. During preharvest deficit irrigation periods defining the treatments rainfall was only $2.5 \mathrm{~mm}$ in 2006/07 and just $0.6 \mathrm{~mm}$ in 2007/08 (Figure 1).

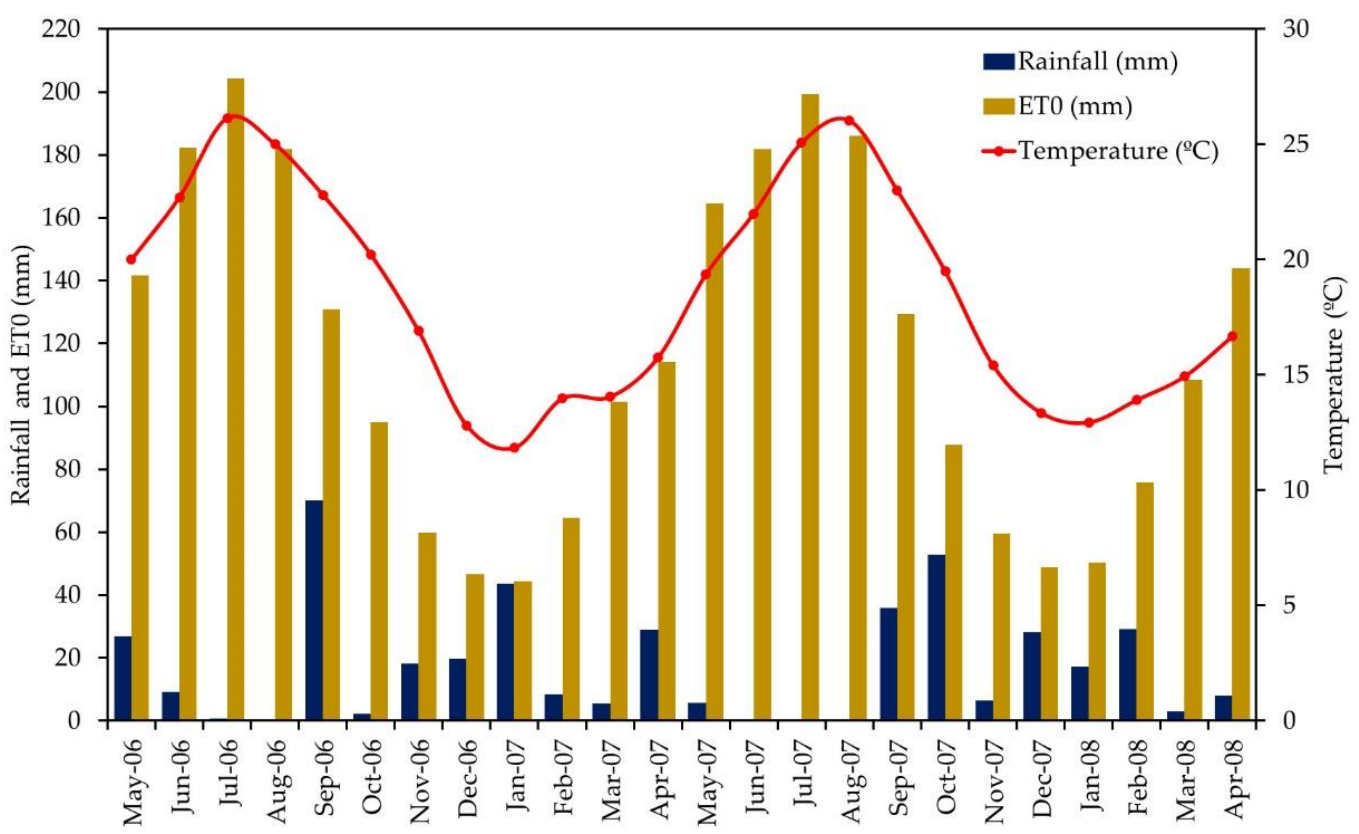

Figure 1. Average temperatures (line), rainfall and evapotranspiration (bars) in the experimental site during both seasons (loquat season start in May and ends in April with the harvest). 
Plot soil is at depth, basic ( $\mathrm{pH}=7.8)$, sandy loam $(72.4 \%$ sand, $14.6 \%$ loam and $13.0 \%$ clay) with low water retention capacity (field capacity $=13.4 \%$, wilting point $=5.1 \%$ ). The 'Algerie' trees used for the experiments were 29 years old, grafted on 'Provence' quince, vase-trained and spaced apart by $6 \times 4 \mathrm{~m}$. Pruning was performed after harvest (June), carrying out a moderate shoot thinning to regulate crop load. In addition to pruning, and to further reduce crop load, flower and fruit thinning were carried out, first using the amide of the naphthaleneacetic acid (NAAm) in late bloom [13], secondly by hand thinning in January to establish a load of four fruits per panicle.

\subsection{Experimental Design and Irrigation Treatments}

Four DI treatments were applied as irrigation withholding during different specific periods in the loquat annual cycle aiming to enhance farmer's profits by reducing irrigation costs, enhancing the positive response of loquat to water stress while minimizing negative effects on fruit size. In this approach, we first determined full water demands based on loquat crop evapotranspiration $\left(\mathrm{ET}_{\mathrm{C}}=\mathrm{ET}_{\mathrm{o}} \times \mathrm{K}_{\mathrm{c}}\right)$. $\mathrm{ET}_{\mathrm{o}}$ was calculated from the readings of a class A pan evaporimeter placed in the orchard, while the crop coefficients $\left(\mathrm{K}_{\mathrm{c}}\right)$ were established based on our extensive experience as 0.50 from May to October (from new shoot growth to bloom); 0.70 from November to January (from bloom to fruit set); 0.75 from February to March (fruit growth phase); and 0.70 in April (fruit ripening) [14].

DI treatments were then established as different combinations of postharvest (preflowering) and preharvest no-irrigation periods of different duration in specific phenological phases. The treatments were labeled as T1: trees not irrigated during a period of six weeks from mid-June to late July (postharvest or pre-flowering DI), but receiving full irrigation in the rest of the season. This treatment represents the recommended irrigation management for loquat growers in the area; T2: trees that, in addition to this period of pre-flowering DI (T1 dry periods), were also not watered from the rapid fruit growth phase determined by Cuevas et al. [15] in the sigmoid fruit growth model (late February-early March depending on the season) until the end of harvest; T3: trees that, in addition to T1 dry periods (pre-flowering DI), had a second period of irrigation withholding at preharvest that started at color break (mid-March) and lasted until the end of harvest; and T4: trees that after the T1 dry period suffered an additional period of water withholding starting at the rapid fruit growth phase but were re-irrigated at color break.

During the periods of irrigation, the experimental trees were watered 2-3 times per week (in fall and winter), four times in spring and up to five times in summer, except during periods of DI (see below in Table 1) when no watering was performed. The water volume effectively applied was registered by multi-jet water meters. Since the phenological stages defining the treatments were reached on different dates in the two experimental seasons, the duration and dates of irrigation withholding periods varied slightly depending on the season. A more detailed description of the irrigation treatments is included in Table 1.

Table 1. Description of the different irrigation treatments: periods of application of postharvest (preflowering) and preharvest DI (no irrigation) including dates, irrigation volumes applied and water savings achieved.

\begin{tabular}{|c|c|c|c|c|}
\hline Treatments & Postharvest DI & Preharvest DI & Irrigation Volumes & Water Savings \\
\hline & & & $\left(\mathrm{m}^{3} \mathrm{ha}^{-1}\right)$ & $(\%)$ \\
\hline \multicolumn{5}{|c|}{$2006 / 07$} \\
\hline Full-irrigated & None & None & 7223 & None \\
\hline $\mathrm{T} 1$ * & 19 June to 29 July & None & 6333 & 12.3 \\
\hline $\mathrm{T} 2$ & 19 June to 29 July & 23 February to 30 April & 4616 & 36.1 \\
\hline $\mathrm{T} 3$ & 19 June to 29 July & 14 March to 30 April & 5025 & 30.0 \\
\hline $\mathrm{T} 4$ & 19 June to 29 July & 23 February to 14 March & 5516 & 23.6 \\
\hline
\end{tabular}


Table 1. Cont.

\begin{tabular}{|c|c|c|c|c|}
\hline Treatments & Postharvest DI & Preharvest DI & Irrigation Volumes & Water Savings \\
\hline \multicolumn{5}{|c|}{ 2007/08 } \\
\hline Full-irrigated & None & None & 7757 & None \\
\hline $\mathrm{T} 1$ & 18 June to 29 July & None & 6307 & 18.7 \\
\hline $\mathrm{T} 2$ & 18 June to 29 July & 3 March to 30 April & 4810 & 38.0 \\
\hline T3 & 18 June to 29 July & 19 March to 30 April & 5284 & 31.9 \\
\hline $\mathrm{T} 4$ & 18 June to 29 July & 3 March to 19 March & 5872 & 24.3 \\
\hline
\end{tabular}

* Full-irrigated: trees receiving full satisfaction of water needs; T1: No irrigation during six weeks after harvest; T2: No irrigation during six weeks after harvest plus nine extra weeks of no irrigation from the rapid fruit growth phase to harvest; T3: No irrigation during six weeks after harvest plus six extra weeks of no irrigation from color break to harvest; and T4: No irrigation during six weeks after harvest plus 2-3 extra weeks (depending on the season) of no irrigation from rapid fruit growth to color break. For more details, see Table 1.

The effects of these DI treatments on yield, fruit quality and consumers' acceptance were analyzed following a complete randomized design with two replicates per treatment. Each replicate was constituted by a row of trees of which the three central trees were chosen for detailed measurements. Fully irrigated 15-year-old 'Algerie' loquat trees, also grafted on 'Provence' quince, vase-trained and $5 \times 5$ spaced, growing in a nearby plot were used as a demonstration reference for farmers to know the actual savings achieved by adopting different DI strategies.

\subsection{Yield and Fruit Quality}

Given the non-climacteric nature of loquat, the harvest was performed every week only on ripen fruits. The effects of DI on fruit earliness were assessed by determining the differences in harvest date and in early yield (\%), as that occurring before 15 April [16]. The average harvest date was calculated for each treatment as the day on which $50 \%$ of the total yield of that treatment was harvested. Fruit weight and diameter were measured on samples of 60 fruits per treatment (30 per replicate) collected from the most representative harvest operation. Additionally, we graded and classified a sample of about $20 \mathrm{~kg}$ obtained from the same most representative harvest operation. The samples were transported to a private packing house (Hercofrut Coop., Almunécar, Spain), where the fruits were classified by the company personnel based on fruit diameter as follow: GGG $>53 \mathrm{~mm}$, $46<\mathrm{GG} \leq 53 \mathrm{~mm}, 32<\mathrm{G} \leq 46 \mathrm{~mm}, 32<\mathrm{M} \leq 28 \mathrm{~mm}$. Fruits having some defects were labeled as second category fruits, regardless of their diameter, while fruits with extensive damages and/or a diameter below $28 \mathrm{~mm}$ were classified as non-commercial. Total yield as the sum of commercial and non-commercial fruits was calculated. Water use efficiency (WUE), as the ratio between total yield and water applied (including irrigation plus rainfall), was also calculated.

Fruit size and quality were estimated in a sample of 60 fruits per treatment (30 fruits per replicate). Fruit size was estimated by its weight and diameter. Fruit quality was estimated by skin color, total soluble solids (TSS) content, titratable acidity (TA), maturity index and fruit firmness. Fruit skin color was measured on each fruit in the CIE $1976 \mathrm{~L}^{*} \mathrm{a}^{*} \mathrm{~b}^{*}$ space color with a colorimeter (model CR200, Konica-Minolta Co., Osaka, Japan), using

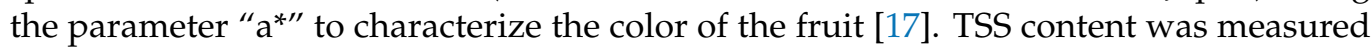
using a digital refractometer (model PAL-1, Atago Co., Tokyo, Japan) from the juice of 30 fruit per replicate; data was expressed in ${ }^{\circ}$ Brix. TA was determined for the same juice by titrating to endpoint $\mathrm{pH} 8.1$ with $0.1 \mathrm{~N} \mathrm{NaOH}$ and expressed as g malic acid $\mathrm{L}^{-1}$. The maturity index was calculated as the ratio between TSS content and TA. Fruit firmness was measured using a force gauge (model EG-50, Mark-10 Co., Copiague, NY, USA) with an $8 \mathrm{~mm}$ tip and $20 \mathrm{~mm} \mathrm{~min}^{-1}$ of speed; data were expressed in $\mathrm{N} \mathrm{cm}^{-2}$. The handling performance of samples of 50 fruit per treatment was assessed after harvest (Figure 2). The fruit was then transported and handled in the above-cited packinghouse, brought back to the lab, evaluated regarding their appearance and again after five days at $20^{\circ} \mathrm{C}$ to simulate fruit performance of the different treatments during shelf life. Fruit damages were assessed using a four-level scale $($ None $=1$; Light $=2$; Moderate $=3$; Severe $=4)$. 


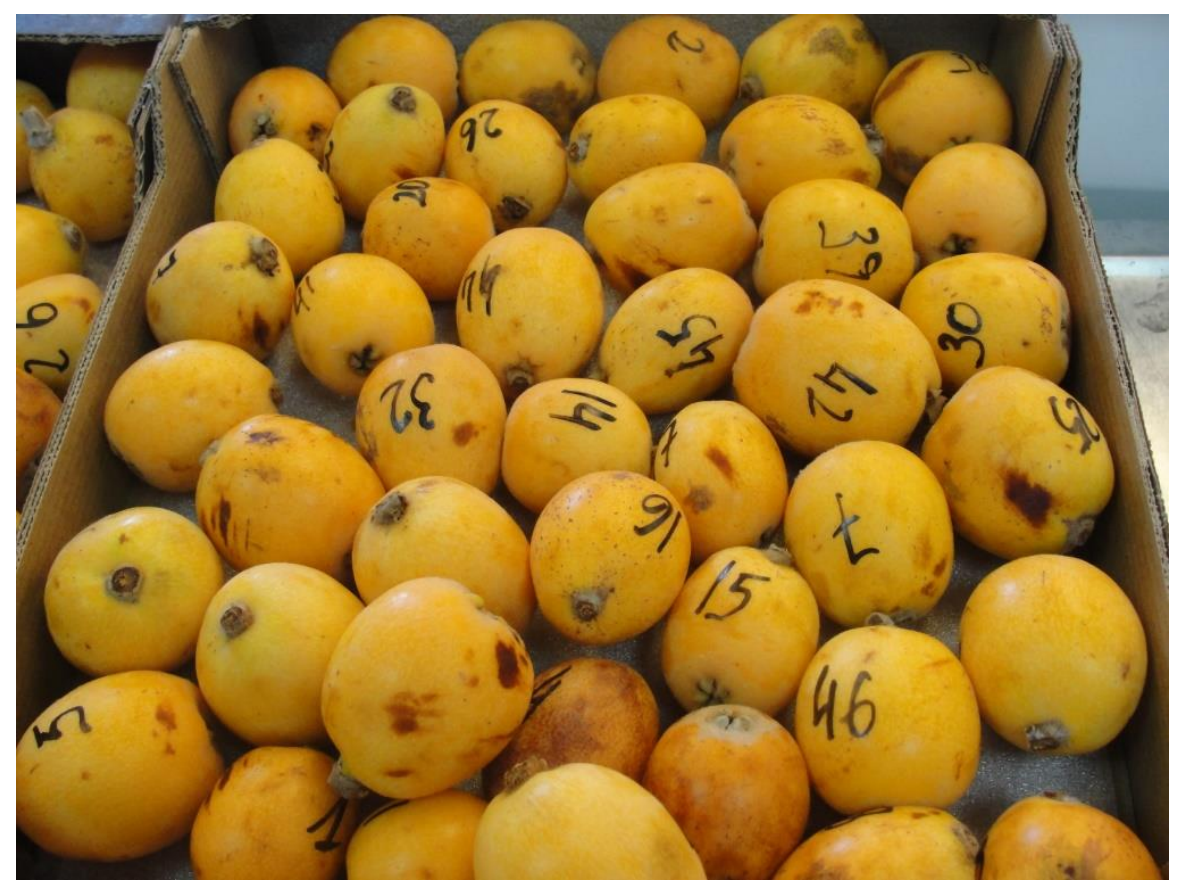

Figure 2. Tagged fruit undergoing handling performance evaluation in a packinghouse.

The acceptance of consumers was explored by sensory evaluations carried out by a panel formed by members of the University of Almería (Spain) of both genders and age between $25-55$ years. Panelists were non-trained. Samples of 20 fruits per treatment were randomly offered to each panelist in a testing-controlled laboratory. External and internal fruit traits were judged by the panelists. External attributes were fruit size, skin color, damages (evaluated by visual defects) and firmness in fingers. Internal attributes were sweetness, acidity, juiciness and hardness in the mouth. In addition, an overall evaluation of external and internal parameters of the samples of each treatment was performed by the panelists and expressed as global acceptance. Each fruit attribute was ranked on a hedonic scale from 1 to 5 (Table 2) as previously described [18]. Each panelist used the whole sample for visual evaluation while 2-3 representative fruits from the sample were used for flavor and texture evaluations.

Table 2. Attributes scored by a sensory evaluation panel to loquat fruit samples.

\begin{tabular}{ccc}
\hline Attribute & & Scale 1-5 \\
\cline { 2 - 3 } & Value $=\mathbf{1}$ & Value $=\mathbf{5}$ \\
\hline Appearance & & \\
Size & Small & Large \\
Color & Bad & Excellent \\
Damages & Very much & None \\
Firmness (in fingers) & Soft & Hard \\
Global Acceptance & Bad & Excellent \\
\hline Flavor and texture & & \\
Sweetness & Non-sweet & Very sweet \\
Acidity & Non-acidic & Very acidic \\
Juiciness & None & Very juicy \\
Hardness (in mouth) & Soft & Hard \\
Global Acceptance & Bad & Excellent \\
\hline
\end{tabular}

Source: Adapted from Cañete et al. [18].

Fruit quality parameters in response to the different DI strategies were compared by analyses of variance (ANOVA), using Statistica 7.0 software. When needed, the means were separated using the Least Significant Different test (LSD) at $p<0.05$. Sensory evaluation 
data were analyzed using a non-parametric Kruskal-Wallis test and comparison tests performed at $p<0.05$.

\section{Results}

$\mathrm{T} 1$ trees received 6333 and $6307 \mathrm{~m}^{3} \mathrm{ha}^{-1}$ in the first and second seasons, respectively. This amount represents water savings between $12-19 \%$ of irrigation depending on the season, with respect to fully irrigated trees $\left(7223 \mathrm{~m}^{3} \mathrm{ha}^{-1}\right.$ and $7757 \mathrm{~m}^{3} \mathrm{ha}^{-1}$ in the first and second season, respectively). T2, T3 and T4 trees were respectively irrigated with 4616,5025 and $5516 \mathrm{~m}^{3} \mathrm{ha}^{-1}$ in 2006/07 and with 4810, 5284 and $5872 \mathrm{~m}^{3} \mathrm{ha}^{-1}$ in 2007/08, meaning that the combination of two periods of DI increased water savings in an extra 19-24\% for T2, 13-18\% for T3 and 5-11\% for T4, depending on the season (Table 1).

Postharvest DI advanced fruit ripening on their own if compared with fully irrigated trees. In this regard, fruit from T1 trees, subjected only to postharvest (preflowering) DI, were harvested 16 and 18 days earlier than the fruit harvested in neighboring fully irrigated trees. Results from trees enduring preharvest DI were even better since all treatments with an extra period of DI enhanced fruit earliness. In this respect, T4 (re-irrigated trees) harvest took place 23 days earlier than in fully irrigated trees in both seasons, while T2 trees did 26 days earlier, also in both seasons. The trees under T3 (with a shorter dry period in preharvest) reached an intermediate advance since the harvest date was 23 days before controls in the first season and 26 days before in the second season. Preharvest DI positive effects on harvest dates were also noted in a higher proportion of early, more profitable, yield (Table 3).

Table 3. Effects of deficit irrigation treatments on fruit earliness (mean harvest date and percentage of early yield obtained before 15 April), total yield and Water Use Efficiency (WUE).

\begin{tabular}{|c|c|c|c|c|c|c|c|c|}
\hline \multirow{2}{*}{ Treatments * } & \multicolumn{2}{|c|}{ Yield (kg Tree $\left.{ }^{-1}\right) * *$} & \multicolumn{2}{|c|}{ Harvest Date } & \multicolumn{2}{|c|}{ Early Yield (\%) } & \multicolumn{2}{|c|}{ WUE $\left(\mathrm{kg} \mathrm{m}^{-3}\right)$} \\
\hline & $2006 / 07$ & $2007 / 08$ & $2006 / 07$ & $2007 / 08$ & $2006 / 07$ & $2007 / 08$ & $2006 / 07$ & $2007 / 08$ \\
\hline $\begin{array}{c}\text { Full- } \\
\text { Irrigated }\end{array}$ & 74.9 & 43.5 & $27 / 04$ & $22 / 04$ & 5.0 & 21.0 & 3.24 & 1.73 \\
\hline $\mathrm{T} 1$ & 81.5 & 56.2 & $11 / 04$ & $04 / 04$ & 63.6 & 88.2 & 4.06 & 2.72 \\
\hline $\mathrm{T} 2$ & 73.7 & 55.9 & $01 / 04$ & $23 / 03$ & 87.5 & 95.8 & 4.62 & 3.27 \\
\hline T3 & 82.3 & 62.1 & $04 / 04$ & $27 / 03$ & 78.6 & 96.4 & 4.86 & 3.41 \\
\hline $\mathrm{T} 4$ & 74.5 & 50.0 & $04 / 04$ & $30 / 03$ & 81.2 & 96.0 & 4.12 & 2.55 \\
\hline
\end{tabular}

* Full-irrigated: trees receiving full satisfaction of water needs; T1: No irrigation during six weeks after harvest; T2: No irrigation during six weeks after harvest plus nine extra weeks of no irrigation from the rapid fruit growth phase to harvest; T3: No irrigation during six weeks after harvest plus six extra weeks of no irrigation from color break to harvest; and T4: No irrigation during six weeks after harvest plus 2-3 extra weeks (depending on the season) of no irrigation from rapid fruit growth to color break. For more details, see Table 1 . ${ }^{* *}$ No significant differences among DI treatments in total and early yield. Full-irrigated trees grown in a nearby plot were not included in the ANOVAs. Harvest dates and WUE are not statistically compared.

Total yield was not reduced by preharvest DI and since additional water savings were achieved, water use efficiency (WUE) was largely improved by preharvest DI (Table 3). While fully irrigated trees produced $3.24 \mathrm{~kg} \mathrm{~m}^{-3}$ of fruit considering rainfall, $\mathrm{T} 1$ trees produced $4.06 \mathrm{~kg} \mathrm{~m}^{-3}$ (25\% more). Adding a dry period during fruit development made the water applied even more efficient. WUE was $4.62,4.86$ and $4.12 \mathrm{~kg} \mathrm{~m}^{-3}$ in T2, T3 and T4, respectively. Yield was reduced in the second season in all treatments and WUE diminished accordingly. Nonetheless, WUE was still much larger in DI treatments. Then, fully irrigated trees produced $1.73 \mathrm{~kg} \mathrm{~m}^{-3}$, while $\mathrm{T} 1$ reached $2.72 \mathrm{~kg} \mathrm{~m}^{-3}$. Once again, the second dry period increased WUE with T2 trees producing an average of $3.27 \mathrm{~kg} \mathrm{~m}^{-3}$ and T3 $3.41 \mathrm{~kg} \mathrm{~m}^{-3}$. The reduced dry period in preharvest made T4 reach a similar WUE $\left(2.55 \mathrm{~kg} \mathrm{~m}^{-3}\right)$ to that observed in T1 (Table 3).

Despite similar yields, preharvest DI slightly reduced fruit weight although the differences were not significant (Table 4). No significant differences were found in fruit diameter either (Table 4). Nevertheless, the distribution of the crop in commercial categories was negatively affected, especially in T2 (Figure 3). In this treatment, more fruits were ascribed 
to the $\mathrm{M}$ size category and to the second and non-commercial categories (around $25 \%$ more fruits than T1 in both seasons) (Figure 3). The same effect was detected for T3 but with less intensity. T4 trees were, on the contrary, largely unaffected (Figure 3).

Table 4. Effects of deficit irrigation treatments on fruit quality parameters. TSS: Total Soluble Solid; Ta: Titratable Acidity.

\begin{tabular}{|c|c|c|c|c|c|c|c|}
\hline Treatments * & Weight ${ }^{*}(g)$ & $\begin{array}{c}\text { Equatorial } \\
\text { Diameter }(\mathrm{mm})\end{array}$ & $\begin{array}{c}\text { TSS } \\
\left({ }^{\circ} \text { Brix }\right)\end{array}$ & $\begin{array}{c}\text { TA (g L }{ }^{-1} \\
\text { Malic) }\end{array}$ & $\begin{array}{l}\text { Maturity } \\
\text { Index }\end{array}$ & $\begin{array}{l}\text { Skin Color (a* } \\
\text { Parameter) }\end{array}$ & $\begin{array}{c}\text { Firmness }(\mathrm{N} \\
\left.\mathrm{cm}^{-2}\right)\end{array}$ \\
\hline \multicolumn{8}{|c|}{$2006 / 07$} \\
\hline $\mathrm{T} 1$ & $47.4 \mathrm{a}$ & $41.0 \mathrm{a}$ & $12.0 \mathrm{~b}$ & $17.0 \mathrm{a}$ & $0.71 \mathrm{a}$ & $8.1 \mathrm{a}$ & $12.8 \mathrm{a}$ \\
\hline $\mathrm{T} 2$ & $42.3 \mathrm{a}$ & $39.8 \mathrm{a}$ & $13.7 \mathrm{a}$ & $13.5 \mathrm{a}$ & $1.06 \mathrm{a}$ & $8.7 \mathrm{a}$ & $12.4 \mathrm{ab}$ \\
\hline $\mathrm{T} 3$ & $43.4 \mathrm{a}$ & $40.3 \mathrm{a}$ & $12.5 \mathrm{~b}$ & $13.4 \mathrm{a}$ & $0.94 \mathrm{a}$ & $9.4 \mathrm{a}$ & $11.8 \mathrm{~b}$ \\
\hline $\mathrm{T} 4$ & $43.7 \mathrm{a}$ & $40.2 \mathrm{a}$ & $12.3 \mathrm{~b}$ & $16.2 \mathrm{a}$ & $0.77 \mathrm{a}$ & $8.5 \mathrm{a}$ & $11.6 \mathrm{~b}$ \\
\hline \multicolumn{8}{|c|}{$2007 / 08$} \\
\hline $\mathrm{T} 1$ & $53.9 \mathrm{a}$ & $41.8 \mathrm{a}$ & $12.2 \mathrm{a}$ & $13.0 \mathrm{a}$ & $0.95 \mathrm{a}$ & $8.9 \mathrm{a}$ & $11.2 \mathrm{a}$ \\
\hline $\mathrm{T} 2$ & $50.9 \mathrm{a}$ & $41.4 \mathrm{a}$ & $12.6 \mathrm{a}$ & $12.6 \mathrm{a}$ & $1.00 \mathrm{a}$ & $9.2 \mathrm{a}$ & $11.2 \mathrm{a}$ \\
\hline T3 & $49.8 \mathrm{a}$ & $41.2 \mathrm{a}$ & $12.2 \mathrm{a}$ & $11.5 \mathrm{a}$ & $1.07 \mathrm{a}$ & $9.3 \mathrm{a}$ & $10.2 \mathrm{a}$ \\
\hline $\mathrm{T} 4$ & $53.8 \mathrm{a}$ & $42.0 \mathrm{a}$ & $12.5 \mathrm{a}$ & $13.3 \mathrm{a}$ & $0.94 \mathrm{a}$ & $9.2 \mathrm{a}$ & $11.2 \mathrm{a}$ \\
\hline
\end{tabular}

* T1: No irrigation during six weeks after harvest; T2: No irrigation during six weeks after harvest plus nine extra weeks of no irrigation from the rapid fruit growth phase to harvest; T3: No irrigation during six weeks after harvest plus six extra weeks of no irrigation from color break to harvest; and T4: No irrigation during six weeks after harvest plus 2-3 extra weeks (depending on the season) of no irrigation from rapid fruit growth to color break. For more details, see Table 1. ${ }^{* *}$ Mean comparison in columns by Least Significant Different (LSD) test at $p<0.05$. Any two means within a column not followed by the same letter are significantly different.

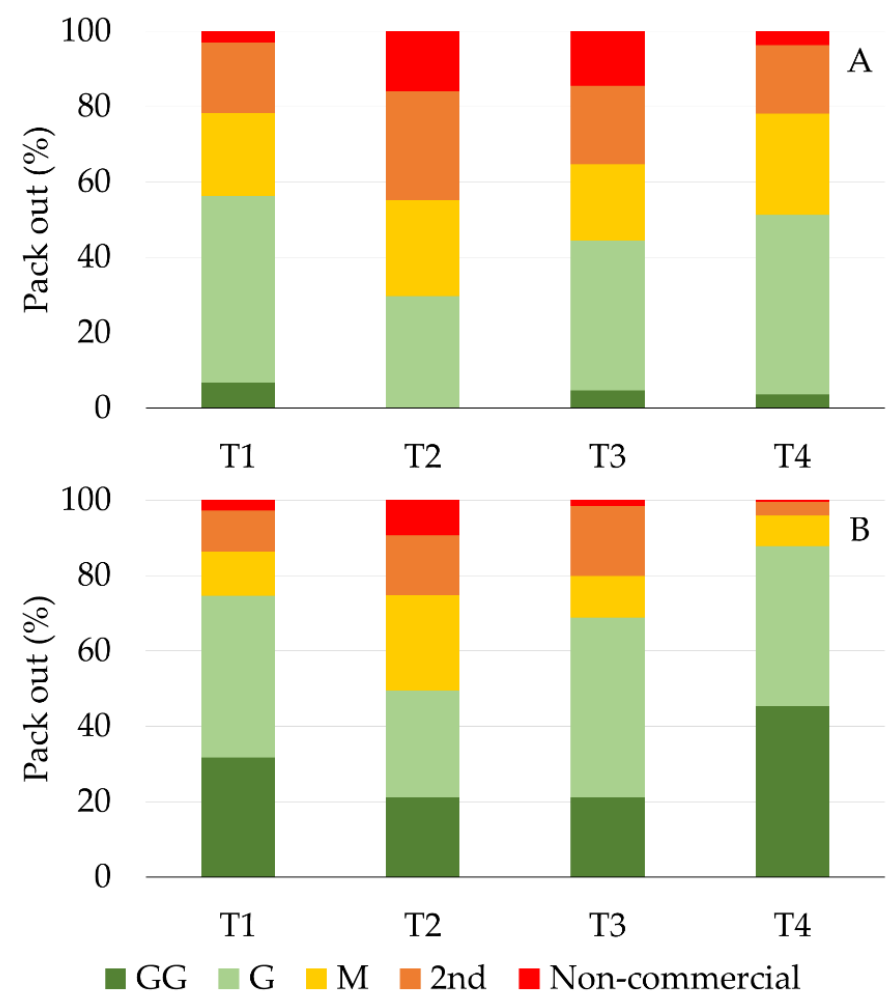

Figure 3. Pack out at harvest as fruit size distribution and damages as follows: GG: $46-52 \mathrm{~mm}$ equatorial fruit diameter; G: 32-45 mm; M: 28-31 mm; 2nd: saleable fruit with slight defects; Noncommercial: unsaleable fruit; evaluated as percentage on a sample of $20 \mathrm{~kg}$ fruit per treatment. (A) = Season 2006/07; (B) = Season 2007/08. T1: No irrigation during six weeks after harvest; T2: No irrigation during six weeks after harvest plus nine extra weeks of no irrigation from rapid fruit growth phase to harvest; T3: No irrigation during six weeks after harvest plus six extra weeks of no irrigation from color break to harvest; and T4: No irrigation during six weeks after harvest plus 2-3 extra weeks (depending on the season) of no irrigation from rapid fruit growth to color break. For more details, see Table 1. 
In the first season (2006/07), an increase of TSS content occurred in response to the longest preharvest DI treatment (T2). These fruits showed similar firmness than T1 but higher than in the other preharvest DI treatments (Table 4). Differences in TSS were not significant in the second season. TA was very high when the irrigation restriction period before harvest was short (T4) or not applied (T1). Nonetheless, the differences were not significant (Table 4). A similar trend of higher TA for T1 and T4 was observed in the second season. Lower TSS and higher TA trends for T1 and T4 were clearly expressed in lower maturity indexes in both seasons. Preharvest DI did not significantly improve the fruit skin color. In the second season, fruits showed better skin color in all treatments and reached higher maturity indexes than the year before (Table 4).

No consistent effects were observed on fruits' appearance after harvest although damages seemed attenuated by some DI treatments. While in the first season, nearly $100 \%$ of fruits of every treatment had a nice appearance and did not show skin damages immediately after harvest, damages were extensive in the second year (Table 5). In this second season, T1 and T3 had only 36 and $40 \%$ of harvested fruits without damages, whereas T2 and T4 had more than half fruits undamaged after harvest (52 and 58\%, respectively). Preharvest DI improved fruit performance during handling at the packinghouse diminishing damages after five days at $20^{\circ} \mathrm{C}$ (Table 5). In the first season, $\mathrm{T} 3$ and T4 reduced fruit skin browning (16-22\%) in comparison with T1. T2 fruits, on the contrary, clearly worsened in appearance after five days of being kept on shelves at $20^{\circ} \mathrm{C}$. The same effect was observed in the second season, but only in T3, reducing up to $18 \%$ the proportion of damaged fruits after five days of shelf life with respect to T1. The effects of DI observed in T2 and T4 fruits were slighter (Table 5).

Table 5. Effects of deficit irrigation treatments on fruit appearance after harvest, handling and five days shelf life at $20{ }^{\circ} \mathrm{C}$. Damage, as percentage of fruits affected, evaluated by a four-level scale $(0=$ None; $1=$ Light; $2=$ Moderate; $3=$ Severe $)$.

\begin{tabular}{|c|c|c|c|c|c|c|c|c|c|c|c|c|}
\hline \multirow[b]{2}{*}{ Damage } & \multicolumn{4}{|c|}{ After Harvest } & \multicolumn{4}{|c|}{ After Handling } & \multicolumn{4}{|c|}{ After Shelf Life } \\
\hline & $\mathbf{0}$ & 1 & 2 & 3 & $\mathbf{0}$ & 1 & 2 & 3 & 0 & 1 & 2 & 3 \\
\hline Treatments * & \multicolumn{4}{|c|}{ Percentage of Total Fruit } & \multicolumn{4}{|c|}{ Percentage of Total Fruit } & \multicolumn{4}{|c|}{ Percentage of Total Fruit } \\
\hline \multicolumn{13}{|c|}{$2006 / 07$} \\
\hline $\mathrm{T} 1$ & 100 & 0 & 0 & 0 & 72.9 & 25.0 & 2.1 & 0 & 60.4 & 37.5 & 2.1 & 0 \\
\hline $\mathrm{T} 2$ & 98 & 2 & 0 & 0 & 74.4 & 20.9 & 2.3 & 2.3 & 51.2 & 44.2 & 2.3 & 2.3 \\
\hline T3 & 96 & 4 & 0 & 0 & 78.3 & 17.4 & 2.2 & 2.2 & 73.9 & 21.7 & 2.2 & 2.2 \\
\hline $\mathrm{T} 4$ & 100 & 0 & 0 & 0 & 70.2 & 29.8 & 0 & 0 & 70.2 & 29.8 & 0 & 0 \\
\hline \multicolumn{13}{|c|}{$2007 / 08$} \\
\hline $\mathrm{T} 1$ & 36 & 48 & 16 & 0 & 24.0 & 56.0 & 20.0 & 0 & 24.0 & 48.0 & 14.0 & 14.0 \\
\hline $\mathrm{T} 2$ & 52 & 28 & 20 & 0 & 51.1 & 29.8 & 19.1 & 0 & 38.3 & 31.9 & 12.8 & 17.0 \\
\hline T3 & 40 & 38 & 22 & 0 & 38.8 & 34.7 & 22.4 & 4.1 & 34.7 & 40.8 & 14.3 & 10.2 \\
\hline $\mathrm{T} 4$ & 58 & 32 & 10 & 0 & 54.0 & 36.0 & 10.0 & 0 & 42.0 & 36.0 & 20.0 & 2.0 \\
\hline
\end{tabular}

* T1: No irrigation during six weeks after harvest; T2: No irrigation during six weeks after harvest plus nine extra weeks of no irrigation from the rapid fruit growth phase to harvest; T3: No irrigation during six weeks after harvest plus six extra weeks of no irrigation from color break to harvest; and T4: No irrigation during six weeks after harvest plus 2-3 extra weeks (depending on the season) of no irrigation from rapid fruit growth to color break. For more details, see Table 1.

The evaluations of the external fruit parameters carried out by the panelists showed variable judgments depending on the season. In the first season, T3 presented the bestscored fruits, while T2 had the worst evaluation. T1 and T4 obtained intermediate scores. Nonetheless, there were no significant differences among DI treatments (Table 6). In the second season, T4 was the best valued and T2 and T3 the worst valued. On this occasion, the differences reached statistical significance (Table 6). These changes in global acceptance were clearly influenced by some specific parameters. In this regard, the analysis of fruit external parameters makes clear the negative effects of preharvest DI treatments on fruit size (Table 6). T2 was the best valued in terms of fruit skin color and firmness in the first year, but these differences were not evident in the next year (Table 6). Regarding damages 
judged by skin defects, no differences were seen between treatments in the first season, but panelists valued $\mathrm{T} 4$ fruits better than $\mathrm{T} 1$ in the second one (Table 6).

Table 6. Effects of deficit irrigation treatments on external attributes scored by a sensory evaluation panel.

\begin{tabular}{|c|c|c|c|c|c|}
\hline Treatments * & $\operatorname{Size}^{* *}$ & Color & Damages & Firmness & Global Acceptance \\
\hline \multicolumn{6}{|c|}{$2006 / 07$} \\
\hline $\mathrm{T} 1$ & $4.09 \mathrm{a}$ & $2.72 \mathrm{~b}$ & $2.59 \mathrm{a}$ & $3.32 \mathrm{~b}$ & $3.13 \mathrm{a}$ \\
\hline $\mathrm{T} 2$ & $1.77 \mathrm{~b}$ & $3.77 \mathrm{a}$ & $2.50 \mathrm{a}$ & $4.04 \mathrm{a}$ & $2.81 \mathrm{a}$ \\
\hline $\mathrm{T} 3$ & $3.54 \mathrm{a}$ & $2.81 \mathrm{~b}$ & $2.86 \mathrm{a}$ & $3.50 \mathrm{ab}$ & $3.40 \mathrm{a}$ \\
\hline $\mathrm{T} 4$ & $3.68 \mathrm{a}$ & $2.45 \mathrm{~b}$ & $3.09 \mathrm{a}$ & $3.13 \mathrm{~b}$ & $3.13 \mathrm{a}$ \\
\hline \multicolumn{6}{|c|}{$2007 / 08$} \\
\hline $\mathrm{T} 1$ & $4.35 \mathrm{a}$ & $2.97 \mathrm{a}$ & $2.58 \mathrm{~b}$ & $3.42 \mathrm{a}$ & $3.42 \mathrm{ab}$ \\
\hline $\mathrm{T} 2$ & $2.19 \mathrm{~b}$ & $3.10 \mathrm{a}$ & $2.97 \mathrm{ab}$ & $3.48 \mathrm{a}$ & $2.81 \mathrm{~b}$ \\
\hline T3 & $2.81 \mathrm{~b}$ & $3.16 \mathrm{a}$ & $2.94 \mathrm{ab}$ & $3.52 \mathrm{a}$ & $2.90 \mathrm{~b}$ \\
\hline $\mathrm{T} 4$ & $3.84 \mathrm{a}$ & $3.23 \mathrm{a}$ & $3.39 \mathrm{a}$ & $3.90 \mathrm{a}$ & $3.84 \mathrm{a}$ \\
\hline
\end{tabular}

* T1: No irrigation during six weeks after harvest; T2: No irrigation during six weeks after harvest plus nine extra weeks of no irrigation from the rapid fruit growth phase to harvest; T3: No irrigation during six weeks after harvest plus six extra weeks of no irrigation from color break to harvest; and T4: No irrigation during six weeks after harvest plus 2-3 extra weeks (depending on the season) of no irrigation from rapid fruit growth to color break. For more details, see Table 1. ${ }^{* *}$ Mean comparison in columns by Kruskal-Wallis multiple range test at $p<0.05$. Any two means within a column not followed by the same letter are significantly different.

Prolonged preharvest DI improved internal fruit quality. According to panelists perception, the fruits from the T2 treatment were sweeter and less acidic than those from T1 and T4 trees. T3 reached an intermediate value (Table 7). For juiciness and hardness, there were no differences among treatments (Table 7). In the second year, no significant response to preharvest deficit irrigation treatments was observed, although the trends for sweetness and acidity were maintained (Table 7). In general, the panelists showed preferences for the fruits of T2 in the global evaluation of internal parameters and valued the fruits of T1 as the worst in both seasons, but without significant differences in 2007/08 (Table 7).

Table 7. Effects of deficit irrigation treatments on internal attributes scored by a sensory evaluation panel.

\begin{tabular}{|c|c|c|c|c|c|}
\hline Treatments * & Sweetness ** & Acidity & Juiciness & Hardness & Global Acceptance \\
\hline \multicolumn{6}{|c|}{$2006 / 07$} \\
\hline $\mathrm{T} 1$ & $1.95 \mathrm{~b}$ & $4.18 \mathrm{a}$ & $3.63 \mathrm{a}$ & $3.27 \mathrm{a}$ & $2.63 \mathrm{~b}$ \\
\hline $\mathrm{T} 2$ & $3.81 \mathrm{a}$ & $2.04 \mathrm{c}$ & $4.09 \mathrm{a}$ & $2.95 \mathrm{a}$ & $4.22 \mathrm{a}$ \\
\hline T3 & $2.72 \mathrm{ab}$ & $3.13 \mathrm{bc}$ & $3.81 \mathrm{a}$ & $3.04 \mathrm{a}$ & $3.36 \mathrm{ab}$ \\
\hline $\mathrm{T} 4$ & $1.95 \mathrm{~b}$ & $3.90 \mathrm{ab}$ & $3.45 \mathrm{a}$ & $3.18 \mathrm{a}$ & $2.63 \mathrm{~b}$ \\
\hline \multicolumn{6}{|c|}{$2007 / 08$} \\
\hline $\mathrm{T} 1$ & $2.65 \mathrm{a}$ & $3.48 \mathrm{a}$ & $3.23 \mathrm{a}$ & $3.29 \mathrm{a}$ & $2.90 \mathrm{a}$ \\
\hline $\mathrm{T} 2$ & $2.97 \mathrm{a}$ & $3.16 \mathrm{a}$ & $3.35 \mathrm{a}$ & $2.81 \mathrm{a}$ & $3.39 \mathrm{a}$ \\
\hline T3 & $2.90 \mathrm{a}$ & $3.39 \mathrm{a}$ & $3.45 \mathrm{a}$ & $2.90 \mathrm{a}$ & $3.13 \mathrm{a}$ \\
\hline $\mathrm{T} 4$ & $2.65 \mathrm{a}$ & $3.45 \mathrm{a}$ & $3.23 \mathrm{a}$ & $3.00 \mathrm{a}$ & $3.16 \mathrm{a}$ \\
\hline
\end{tabular}

* T1: No irrigation during six weeks after harvest; T2: No irrigation during six weeks after harvest plus nine extra weeks of no irrigation from the rapid fruit growth phase to harvest; T3: No irrigation during six weeks after harvest plus six extra weeks of no irrigation from color break to harvest; and T4: No irrigation during six weeks after harvest plus 2-3 extra weeks (depending on the season) of no irrigation from rapid fruit growth to color break. For more details, see Table 1. ${ }^{* *}$ Mean comparison in columns by Kruskal-Wallis multiple range test at $p<0.05$. Any two means within a column not followed by the same letter are significantly different.

\section{Discussion}

Water savings were largely increased by a wise combination of pre and postharvest DI in 'Algerie' loquat (Table 1). In this regard, the best combination of pre and postharvest DI allowed savings of near $3000 \mathrm{~m}^{3} \mathrm{ha}^{-1}$, compared to fully irrigated trees (Table 1), which are supposed to be near $38 \%$ of the water volumes applied to controls. Since loquat yield was not significantly reduced, DI increased WUE. 
DI might have other favorable effects on loquat fruit. In this regard, postharvest DI enhances loquat earliness [4-6,19] as once again has been verified here (Table 3). Even more, water deficit periods during fruit development further improved loquat earliness (and price) advancing harvest by between one and two additional weeks, increasing farmers' revenues. Thus, the earliest harvest was carried out in T2 trees (trees having the longest, nine-week preharvest dry period) in which the harvest was advanced by 10-12 additional days. T3, with a shorter preharvest DI (six weeks), advanced the harvest less (7-8 days more) as did T4 (5-7 days extra) also with a short dry period (2-3 weeks) during fruit growth (T4). Other authors have reported earlier fruit maturity by preharvest DI in apples [20-23] and pears [24,25]. This advance seems related to an increase of ethylene in fruits subjected to DI $[20,23]$.

Opposite to the beneficial effects, preharvest DI may have a negative effect on fruit growth. Smaller fruit size is common after preharvest DI as observed in apples [22,23,26-29] and pears [30]. This negative effect depends, however, on the date, severity and duration of the water deficit period [10,23]. Our results show that T2, as well as T3, had reduced fruit size, producing more unsaleable fruit (Figure 3). This negative effect did not occur if re-irrigation was put into practice. Thus, $\mathrm{T} 4$ presented very similar fruit distribution into categories to that found in T1 (Figure 3). Compensatory fruit growth after re-irrigation has been suggested as the mechanism allowing fruit size recovery [31-33], although detailed fruit growth rates have been rarely documented.

Other common positive effects of DI are an increase in TSS content and an improvement in pulp firmness and skin color of the fruit [8-10,34]. In our experiments, we only observed sweeter and less acidic fruit under T2; this fruit, for these reasons, was preferred by the panelists (Table 7), but apart from this, no other consistent changes were detected.

Finally, loquat is harvested by hand and requires careful handling during classification and transport to minimize fruit damage, extensive in this crop due to its very delicate condition. Loquat has also an extreme susceptibility to browning due to the high activity of the enzyme phenol-oxidase in fruit tissues [35]. Reduced damage was pursued in this experiment using different DI strategies and achieved in response to T3 and T4 treatments, but not in response to T2. Fruit susceptibility to damages is exacerbated in fully irrigated trees due to the increased cell turgor (Guelfat'Reich and Ben-Arie, cited by Behboudian and Mills) [36]. Fruit maturity clearly interacts with firmness, and some treatments tend to advance fruit maturity. Increased, diminished or unaffected flesh firmness of the fruit has been reported after preharvest DI in different pome crops [20-22].

In summary, preharvest DI increased water savings to a large extent and thus enhanced WUE over a long period of DI (nine weeks; T2) produced sweeter and more precocious fruit, but of a smaller size. Fruits obtained under a shorter preharvest DI (six weeks; T3) had their size reduced just a little and kept a better appearance after shelf life. In our opinion, the most promising treatment was T4, since these fruits were as precocious and sweet as the fruit from T3 and they were larger, having, in addition, better aptitude for handling and longer shelf life. Water savings were certainly less in this treatment.

Author Contributions: Investigation, Methodology, Writing-original draft, Validation, J.J.H.; Investigation (field data), F.A.; Investigation (sensorial analyses), Writing—review and editing analyses, M.L.C.; Investigation (field data), M.G.; Investigation (fruit quality analyses), V.P.; Data curation, Writing-review and editing, F.M.C.; Conceptualization, Methodology, Writing-review and editing, Supervision, Funding acquisition, J.C. All authors have read and agreed to the published version of the manuscript.

Funding: This research was partially funded by project AGR-03183 granted by the Junta de Andalucía with European Union (FEDER) funds.

Data Availability Statement: Data available on request to authors.

Acknowledgments: We would like to thank the Cajamar Research Centre, which kindly provided means and personnel. 
Conflicts of Interest: The authors declare no conflict of interest. The funders had no role in the design of the study; in the collection, analyses, or interpretation of data; in the writing of the manuscript, or in the decision to publish the results.

\section{References}

1. Lin, S.Q.; Sharpe, R.H.; Janick, J. Loquat: Botany and Horticulture. Hortic. Rev. 1999, 23, 233-276. [CrossRef]

2. Badenes, M.L.; Blasco, M.; Naval, M.M. Loquat: Progress and Expectations. Acta Hortic. 2015, 1092, 19-24. [CrossRef]

3. MAPA. Ministerio de Agricultura, Pesca y Alimentación. Datos Provisionales de Frutales No Cítricos y Frutales Secos año 2019. Spain. Available online: https://www.mapa.gob.es/es/estadistica/temas/estadisticas-agrarias/agricultura/superficiesproducciones-anuales-cultivos/ (accessed on 2 November 2020).

4. Hueso, J.J.; Cuevas, J. Loquat as a crop model for successful deficit irrigation. Irrig. Sci. 2008, 26, 269-276. [CrossRef]

5. Cuevas, J.; Cañete, M.L.; Pinillos, V.; Zapata, A.J.; Fernández, M.D.; González, M.; Hueso, J.J. Optimal dates for regulated deficit irrigation in 'Algerie' loquat (Eriobotrya japonica Lindl.) cultivated in Southeast Spain. Agric. Water Manag. 2007, 89, 131-136. [CrossRef]

6. Cuevas, J.; Pinillos, V.; Cañete, M.L.; González, M.; Alonso, F.; Fernández, M.D.; Hueso, J.J. Optimal levels of postharvest deficit irrigation for promoting early flowering and harvest dates in loquat (Eriobotrya japonica Lindl.). Agric. Water Manag. 2009, 96, 831-838. [CrossRef]

7. Cuevas, J.; Pinillos, V.; Cañete, M.L.; Parra, S.; González, M.; Alonso, F.; Fernández, M.D.; Hueso, J.J. Optimal duration of irrigation withholding to promote early bloom and harvest in 'Algerie' loquat (Eriobotrya japonica Lindl.). Agric. Water Manag. 2012, 111, 79-86. [CrossRef]

8. Naor, A. Irrigation scheduling and evaluation of tree water status in deciduous orchards. Hortic. Rev. 2006, 32, 111-165. [CrossRef]

9. Pérez-Sarmiento, F.; Mirás-Avalos, J.M.; Alcobendas, R.; Alarcón, J.J.; Mounzer, O.; Nicolás, E. Effects of regulated deficit irrigation on physiology, yield and fruit quality in apricot trees under Mediterranean conditions. Span. J. Agric. Res. 2016, 14, e1205. [CrossRef]

10. Carrasco-Benavides, M.; Meza, S.E.; Olguín-Cáceres, J.; Muñoz-Concha, D.; von Bennewitz, E.; Ávila-Sánchez, C.; Ortega-Farías, S. Effects of regulated post-harvest irrigation strategies on yield, fruit quality and water productivity in a drip-irrigated cherry orchard. N. Z. J. Crop Hortic. Sci. 2020, 48, 97-116. [CrossRef]

11. Blanco, V.; Martínez-Hernández, G.B.; Artés-Hernández, F.; Blaya-Ros, P.J.; Torres-Sánchez, R.; Domingo, R. Water relations and quality changes throughout fruit development and shelf life of sweet cherry grown under regulated deficit irrigation. Agric. Water Manag. 2019, 217, 243-254. [CrossRef]

12. Hueso, J.J.; Alonso, F.; Cañete, M.L.; González, M.; Pinillos, V.; Cuevas, J. The combination of pre- and post-harvest deficit irrigation improves loquat fruits earliness and performance at packing houses. Acta Hortic. 2013, 975, 275-280. [CrossRef]

13. Cuevas, J.; Moreno, M.; Esteban, A.; Martínez, A.; Hueso, J.J. Chemical fruit thinning in loquat with NAAm: Dosage, timing and wetting agent effects. Plant Growth Regul. 2004, 43, 145-151. [CrossRef]

14. Hueso, J.J.; Cuevas, J. Ten consecutive years of regulated deficit irrigation probe the sustainability and profitability of this water saving strategy in loquat. Agric. Water Manag. 2010, 97, 645-650. [CrossRef]

15. Cuevas, J.; Salvador-Sola, F.J.; Gavilán, J.; Lorente, N.; Hueso, J.J.; González-Padierna, C.M. Loquat fruit sink strength and growth pattern. Sci. Hortic. 2003, 98, 131-137. [CrossRef]

16. Gariglio, N.; Castillo, Á.; Juan, M.; Almela, V.; Agustí, M. El Níspero Japonés. Técnicas Para Mejorar la Calidad del Fruto; Sèrie Divulgació Técnica no 52; Consellería de Agricultura, Pesca y Alimentación de la Generalitat Valenciana: Valencia, Spain, 2002.

17. Amorós, A.; Zapata, P.; Pretel, M.T.; Botella, M.A.; Serrano, M. Physico-chemical and physiological changes during fruit development and ripening of five loquat (Eriobotrya japonica Lindl.) cultivars. Food Sci. Technol. Int. 2003, 9, 43-51. [CrossRef]

18. Cañete, M.L.; Pinillos, V.; Cuevas, J.; Hueso, J.J. Sensory evaluation of the main loquat cultivars in Spain. Acta Hortic. 2007, 750, 159-164. [CrossRef]

19. Cuevas, J.; Hueso, J.J.; Rodríguez, M.C. Deficit irrigation as a tool for manipulating flowering date in loquat (Eriobotrya japonica Lindl.). In Agricultural Water Management Research Trends; Sorensen, M.L., Ed.; Nova Science Publisher Inc.: New York, NY, USA, 2008; pp. 237-253.

20. Ebel, R.C.; Proebsting, E.L.; Patterson, M.E. Regulated deficit irrigation may alter apple maturity, quality and storage life. HortSci. 1993, 28, 141-143. [CrossRef]

21. Mills, T.M.; Behboudian, M.H.; Tan, P.Y.; Clothier, B.E. Plant water status and fruit quality in 'Braeburn' apples. HortSci. 1994, 29, 1274-1278. [CrossRef]

22. Mpelasoka, B.S.; Behboudian, M.H.; Dixon, J.; Neal, S.M.; Caspari, H.W. Improvement of fruit quality and storage potential of 'Braeburn' apple through deficit irrigation. J. Hortic. Sci. Biotechnol. 2000, 75, 615-621. [CrossRef]

23. Mpelasoka, B.; Behboudian, M.; Green, S. Water use, yield and fruit quality of lysimeter-grown apple trees: Responses to deficit irrigation and to crop load. Irrig. Sci. 2001, 20, 107-113. [CrossRef]

24. Caspari, H.W.; Behboudian, M.H.; Chalmers, D.J.; Clothier, B.E.; Lenz, F. Fruit characteristics of 'Hosui' Asian pears after deficit irrigation. HortSci. 1996, 31, 162. [CrossRef]

25. Raese, J.T.; Brun, C.A.; Seeley, E.J. Effect of irrigation regimes and supplemental nitrogen on alfalfa greening, cork spot and fruit quality of d'Anjou pears. HortScience 1982, 17, 666-668. 
26. Ebel, R.C.; Proebsting, E.L.; Evans, R.G. Apple tree and fruit responses to early termination of irrigation in a semi-arid environment. HortScience 2001, 36, 1197-1201. [CrossRef]

27. Naor, A.; Klein, I.; Doron, I. Stem water potential and apple fruit size. J. Am. Soc. Hortic. Sci. 1995, 120, 577-582. [CrossRef]

28. Naor, A.; Klein, I.; Doron, I.; Gal, Y.; Ben-David, Z.; Bravdo, B. Irrigation and fruit level interactions in relation to yield and fruit size distribution. J. Am. Soc. Hortic. Sci. 1997, 122, 411-414. [CrossRef]

29. Naor, A.; Klein, I.; Doron, I.; Gal, Y.; Ben-David, Z.; Bravdo, B. The effect of irrigation and crop load on stem water potential and apple fruit size. J. Hortic. Sci. 1997, 72, 765-771. [CrossRef]

30. Naor, A.; Peres, M.; Greenblat, Y.; Doron, I.; Gal, Y.; Stern, R.A. Irrigation and crop load interactions in relation to pear yield and fruit-size distribution. J. Hortic. Sci. Biotechnol. 2000, 75, 555-561. [CrossRef]

31. Chalmers, D.J.; Burge, G.; Jerie, P.H.; Mitchell, P.D. The mechanism of regulation of 'Bartlet' pear fruit and vegetative growth by irrigation withholding and regulated deficit irrigation. J. Am. Soc. Hortic. Sci. 1986, 111, 904-907.

32. Mitchell, P.D.; Chalmers, D.J.; Jerie, P.H.; Burge, G. The use of initial withholding of irrigation and tree spacing to enhance the effect of regulated deficit irrigation on pear trees. J. Am. Soc. Hortic. Sci. 1986, 111, 858-861.

33. Mitchell, P.D.; van den Ende, B.; Jerie, P.H.; Chalmers, D.J. Responses of 'Barlett' pear to withholding irrigation, regulated deficit irrigation and tree size spacing. J. Am. Soc. Hortic. Sci. 1989, 114, 15-19.

34. Adu, M.O.; Yawson, D.O.; Abano, E.E.; Asare, P.A.; Armah, F.A.; Opoku, E.K. Does water-saving irrigation improve the quality of fruits and vegetables? Evidence from meta-analysis. Irrig. Sci. 2019, 37, 669-690. [CrossRef]

35. Sellés-Marchart, S. Pardeamiento Enzimático del Fruto del Níspero (Eriobotrya japonica cv. Algerie): Enzimología y Fisiología de las Polifenol Oxidasas; University of Alicante: Alicante, Spain, 2007.

36. Behboudian, M.H.; Mills, T.M. Deficit irrigation in deciduous orchards. In Horticultural Reviews; Janick, J., Ed.; Wiley: New York, NY, USA, 1997; Volume 21, pp. 105-131. [CrossRef] 